\title{
Analisis Kelayakan TPA Regional untuk Wilayah Pelayanan Kota Jakarta Barat, Kabupaten Tangerang, Kota Tangerang, dan Kabupaten Serang Ditinjau dari Pemilihan Teknologi Pengolahan Sampah, Pembiayaan, dan Institusi
}

\author{
Arie Fernando \\ Dinas Perumahan dan Gedung Pemda Propinsi DKI Jakarta \\ email: a_nando@email.com
}

\begin{abstract}
Abstrak
Permasalahan sampah di Indonesia tidak hanya berakibat buruk pada lingkungan tapi sudah merenggut korban jiwa. Tahun 2006 di TPA Bantargebang tiga orang meninggal terkubur sampah. Pada tahun 2003 masa pengoperasian TPA Bantar Gebang telah berakhir. Saat itu Pemprop DKI Jakarta melakukan pembuangan sampah ke TPA Cilincing, Jakarta Utara. Pembuangan sampah dilakukan dengan cara open dumping sehingga menyebabkan petambak menanggung kerugian hingga puluhan juta rupiah. Kabupaten dan Kota Tangerang serta Kabupaten Serang sebagai daerah penyangga Ibukota Jakarta mempunyai masalah yang sama dalam pengelolaan sampah. Penelitian dilakukan untuk menentukan teknologi pengolahan sampah di TPA regional, mengidentifikasi potensi pembiayaan pengolahan sampah, dan mengidentifikasi bentuk kelembagaan pengolahan sampah untuk Kota Jakarta Barat, Kabupaten dan Kota Tangerang serta Kabupaten Serang dengan konsep TPA regional. Metode untuk menjawab tujuan penelitian menggunakan analisis SWOT, metode analisis manfaat biaya dan analisis deskriptif. Hasil penelitian menyimpulkan bahwa teknologi pengolahan sampah dengan analisis SWOT untuk TPA regional daerah Kota Jakarta Barat, Kabupaten dan Kota Tangerang, serta Kabupaten Serang adalah pengkomposan dan sanitary landfill. Pembiayaan TPA regional membutuhkan dana sekitar Rp 207 milyar. Lembaga pengelola TPA regional berbentuk Badan Layanan Umum (BLU). Untuk mendukung terlaksananya TPA regional daerah Kota Jakarta Barat, Kabupaten dan Kota Tangerang, serta Kabupaten Serang perlu diambil langkah melakukan studi daya dukung sosial pada bakal calon lokasi TPA regional untuk mengetahui potensi penerimaan masyarakat terhadap rencana TPA regional dan memulai proses kerjasama antar daerah di bidang persampahan.
\end{abstract}

Kata kunci: TPA regional, pengolahan sampah, pembiayaan, dan kelembagaan

\section{Pendahuluan}

Permasalahan sampah di Indonesia tidak hanya berakibat buruk pada lingkungan tapi sudah merenggut korban jiwa. Peristiwa longsornya Tempat Pembuangan Akhir (TPA) Leuwigajah yang menewaskan 143 orang pada bulan Februari 2005 terulang kembali pada bulan September 2006 di TPA Bantargebang yang mengakibatkan tiga orang meninggal. Bulan Desember tahun 2003 waktu pengoperasian TPA Bantar Gebang telah berakhir. Di saat negosiasi perpanjangan penggunaan TPA Bantar Gebang, Pemprop DKI Jakarta melakukan pembuangan sampah ke TPA Cilincing di Desa Rorotan, Rawa Malang, Cilincing Jakarta Utara. Pembuangan sampah dilakukan dengan cara open dumping sehingga puluhan hektar areal tambak dan sawah rusak berat akibat lindi (leachate) yang dihasilkan dari pembusukan sampah. Pencemaran lindi ke dalam areal tambak menyebabkan petambak menanggung kerugian hingga puluhan juta rupiah belum lagi bau yang ditimbulkan. Kabupaten dan Kota Tangerang serta Kabupaten Serang sebagai daerah penyangga Ibukota Jakarta 
mempunyai masalah yang sama dalam pengelolaan sampah yang dialami oleh sebagian besar kotakota besar di Indonesia. Selain permasalahan teknis dalam pengelolaan sampah, juga terdapat permasalahan kelembagaan atau institusi pengelola persampahan yang belum efektif dan efisien.

Tujuan penelitian adalah untuk: (1) menentukan teknologi pengolahan sampah di TPA regional yang sesuai dengan komposisi dan timbulan sampah daerah layanan (Kota Jakarta Barat, Kabupaten dan Kota Tangerang serta Kabupaten Serang), (2) mengidentifikasi potensi pembiayaan pengolahan sampah untuk daerah layanan dengan konsep TPA regional, (3) mengidentifikasi bentuk kelembagaan pengolahan sampah untuk daerah layanan konsep TPA regional.

\section{Metode Penelitian}

Penelitian ini menggunakan pendekatan penelitian secara kuantitatif dan juga menggunakan data kualitatif. Berdasarkan sifat dasar penelitian, penelitian ini tergolong penelitian ex post facto dengan survei lapangan pengkajian perencanaan pengelolaan sampah dengan TPA regional.

Penelitian dilakukan selama tiga bulan dari bulan Januari sampai dengan bulan April 2007. Penelitian dilakukan di daerah Kota Jakarta Barat, Kabupaten dan Kota Tangerang, serta Kabupaten Serang dengan mempertimbangkan birokrasi, perolehan ijin penelitian, dan keterbukaan informasi di organisasi penelitian.

Populasi umum dalam penelitian ini adalah semua pemangku kepentingan di bidang persampahan di daerah Kota Jakarta Barat, Kabupaten dan Kota Tangerang, serta Kabupaten Serang. Sedangkan populasi targetnya adalah pemangku kepentingan bidang persampahan yang mengikuti atau terlibat aktif dalam masalah persampahan di daerah Kota Jakarta Barat, Kabupaten dan Kota Tangerang, serta Kabupaten Serang.

Tabel 1. Data Penelitian

\begin{tabular}{|c|l|c|c|}
\hline No & \multicolumn{1}{|c|}{ Variabel } & Satuan & Jenis Data \\
\hline 1. & Timbulan sampah & $\mathrm{m}^{3} /$ hari & Sekunder \\
\hline 2. & Komposisi sampah & Tidak bersatuan & Sekunder \\
\hline 3. & Sarana dan prasarana & Tidak bersatuan & Sekunder \\
\hline 4. & Instansi pengelola persampahan & Rupiah & Sekunder \\
\hline 5. & Anggaran pengelolaan persampahan & Rupiah & Sekunder \\
\hline 6. & Tarif retribusi & Tidak bersatuan & Sekunder, Primer \\
\hline 7. & Kondisi bakal calon lokasi TPA regional & Tidak bersatuan & Primer \\
\hline 8. & $\begin{array}{l}\text { Aspek-aspek terkait teknologi pengolahan } \\
\text { sampah yaitu aspek sosial, teknis, lingkungan, } \\
\text { dan ekonomi }\end{array}$ & \\
\hline
\end{tabular}


Responden yang diwawancara pada penelitian ini sebanyak 15 orang yang merupakan bagian dari instansi yang menangani masalah persampahan di daerah, instansi/dinas pengelolaan lingkungan hidup, LSM, dan akademisi. Penentuan responden dilakukan secara purposive sampling yaitu responden terpilih ditentukan berdasarkan informasi dan keterangan dari pemangku kepentingan yang terkait dengan masalah persampahan.

\section{Hasil dan Pembahasan}

\section{Gambaran Umum Daerah Penelitian}

Penelitian ini dilakukan pada empat daerah yang saling berdekatan yaitu Kota Jakarta Barat, Kota Tangerang, Kabupaten Tangerang, dan Kabupaten Serang. Profil masing-masing daerah disajikan pada Tabel 2.

Tabel 2. Profil Daerah Penelitian

\begin{tabular}{|l|l|l|l|l|}
\hline \multicolumn{1}{|c|}{ Keterangan } & Kota JakBar & Kota Tangerang & Kab Tangerang & Kab Serang \\
\hline Luas daerah $\left(\mathrm{Km}^{2}\right)$ & 126,15 & 183,78 & $1.110,38$ & $1.734,09$ \\
\hline Jumlah Kecamatan & 8 & 13 & 26 & 32 \\
\hline Jumlah Penduduk (jiwa) & 1.563 .563 & 1.537 .244 & 3.324 .949 & 1.866 .512 \\
\hline Laju Pertumbuhan Penduduk (\%) & 0,46 & $2,83^{*}$ & $2,83^{*}$ & $2,83^{*}$ \\
\hline
\end{tabular}

Keterangan: * Laju pertumbuhan penduduk Provinsi Banten Tahun 2000-2005 (BPS, 2006)

Daerah penelitian mencakup dua provinsi yaitu Kota Jakarta Barat masuk dalam Provinsi DKI Jakarta sedangkan Kota Tangerang, Kabupaten Tangerang, dan Kabupaten Serang masuk dalam Provinsi Banten. Kondisi topografi wilayah pada umumnya relatif datar dengan ketinggian antara 0$85 \mathrm{~m}$ di atas permukaan laut (dpl) kecuali Kabupaten Serang di mana terdapat wilayah yang ketinggiannya mencapai $500 \mathrm{~m}$ dpl. Temperatur rata-rata sepanjang tahun wilayah tersebut berkisar antara $22,1^{\circ} \mathrm{C}$ sampai $32,7^{\circ} \mathrm{C}$ dengan kelembaban relatif antara $80 \%$ hingga $90 \%$ (BPS, 2006).

Kondisi tata guna lahan di Kota Jakarta Barat terdiri atas 8.599, 27 ha (68,16\%) untuk perumahan, 495,77 ha (3,92\%) untuk industri, 1.451,98 (11,05\%) untuk perkantoran dan pergudangan, 127,41 ha $(1,01 \%)$ untuk taman, serta 1.980,55 ha (15,86\%) untuk penggunaan lain (DirJend Penataan Ruang-Dep PU, 2003). Pola penggunaan lahan di Kota Tangerang dapat dikelompokkan ke dalam dua kategori, yaitu kawasan budidaya dan kawasan lindung. Luas kawasan lindung di Kota Tangerang adalah seluas 278 ha (1,50\%) dari total luas lahan. Kawasan lindung ini diantaranya meliputi kawasan Situ Cipondoh dan kawasan sempadan sungai. Kawasan budidaya meliputi kawasan yang sudah terbangun sebesar 12.331 ha (69,55\%) yang terdiri atas permukiman 5.988,2 ha, industri 1.367,1 ha perdagangan dan jasa 608,1 ha, pertanian 4.467,8 ha, Bandara Soekarno Hatta 1.816,0 ha dan lain-lain 819,4 ha. Sedangkan kawasan belum terbangun seluas 5.398,746 ha (30,45 \%) (Dinas Informasi Tangerang, 2003). 
Tata guna lahan Kabupaten Tangerang berdasarkan basis data Departemen Kehutanan (Dephut) tahun 2004 didominasi untuk permukiman sebanyak 39\% kemudian lahan sawah sebesar 37\%. Sedangkan pola penggunaan lahan di Kabupaten Serang lebih didominasi lahan sawah sebesar 35\% dan hutan sekitar 46\% (Dephut, 2004).

\section{Sistem pengelolaan sampah saat ini}

Secara umum sistem pengelolaan sampah oleh pengelola persampahan di daerah yang berjalan di hampir seluruh daerah di Indonesia memiliki pola kumpul, angkut, dan buang. Begitu juga yang terjadi di Kota Jakarta Barat, Kota Tangerang, Kabupaten Tangerang, dan Kabupaten Serang digambarkan dalam satu diagram pada Gambar di bawah. Sampah yang berasal dari berbagai sumber yaitu permukiman, perkantoran, industri, dan penyapuan jalan dikumpulkan dalam berbagai jenis wadah. Dari wadah pengumpulan seperti tong sampah, kontainer maupun bak beton diangkut ke TPS yang kemudian dibawa truk pengangkut sampah menuju TPA.

Selain sistem yang berjalan dengan cara tersebut ada juga sistem informal yang melibatkan pemulung, lapak, dan bandar, baik itu di lingkungan permukiman maupun di sekitar lokasi TPA. Sistem informal ini umum terjadi di negara berkembang yang belum memiliki sistem pengelolaan sampah terpadu yang mencakup lima aspek pengelolaan persampahan.

Data mengenai aspek teknik operasional pengelolaan sampah yang ada di Kota Jakarta Barat, Kota Tangerang, Kabupaten Tangerang, dan Kabupaten Serang disajikan pada Tabel 3 dan Tabel 4.

Berdasarkan Tabel 3 dan 4 sebelumnya memperlihatkan pelayanan pengelolaan sampah oleh masing-masing institusi yang menangani masalah persampahan masih belum memadai. Berkisar antara 19\% untuk Kabupaten Tangerang sampai 30\% untuk Kabupaten Serang dari seluruh timbulan sampah yang dihasilkan. Kecuali Suku Dinas Kebersihan Jakarta Barat yang telah menanggulangi timbulan sampah hingga 98\%. Tingginya tingkat penanggulangan sampah Sudin Kebersihan Jakbar terkait dengan daerah Jakbar yang menjadi bagian DKI Jakarta. Status DKI Jakarta yang menjadi ibukota negara RI diupayakan memiliki citra wilayah yang bebas dari sampah sehingga didukung dengan sarana dan anggaran yang lebih banyak. Selain itu masih belum lengkapnya basis data mengenai karakteristik dan komposisi sampah di Kabupaten Tangerang menunjukkan masih rendahnya perhatian instansi terkait dalam menangani sampah meski sudah ditangani institusi setingkat dinas. Kabupaten Serang yang wilayahnya paling luas sebesar 1.734,03 $\mathrm{km}^{2}$ dengan 34 kecamatan hanya mampu menangani sampah yang berada di daerah Serang kota yang terdiri atas enam kecamatan. Jumlah timbulan sampah yang tidak tertanggulangi diperkirakan sebagian besar berada di wilayah perdesaan ditangani sendiri oleh masyarakat dengan cara dibakar atau ditimbun di tempat liar. 
Tabel 3. Data Timbulan Sampah di Kota Jakarta Barat, Kabupaten dan Kota Tangerang, serta Kabupaten Serang

\begin{tabular}{|c|c|c|c|c|}
\hline KETERANGAN & KOTA JAKARTA BARAT & KOTA TANGERANG & KAB TANGERANG & KAB SERANG \\
\hline \multicolumn{5}{|l|}{ I. Institusi pengelola } \\
\hline $\begin{array}{l}\text { 1. Nama } \\
\text { 2. Alamat } \\
\text { 3. Telepon }\end{array}$ & $\begin{array}{l}\text { Suku Dinas Kebersihan Jak-Bar } \\
\text { Dinas Kebersihan DKI Jakarta } \\
\text { Jl. Perdana No 10, Jelambar } \\
\text { 021-5663524 }\end{array}$ & $\begin{array}{l}\text { Suku Dinas Kebersihan Tangerang } \\
\text { Dinas Pekerjaan Umum Tangerang } \\
\text { Jl. KS. Tubun No. 96, Tangerang } \\
\text { 021-5534067 }\end{array}$ & $\begin{array}{l}\text { Dinas Kebersihan dan Pertamanan } \\
\text { JI.P. Kemerdekaan No.575, Cikokol } \\
\text { 021-5523224 }\end{array}$ & $\begin{array}{l}\text { Bidang Kebersihan Kab Serang } \\
\text { Dinas PU Kab Serang } \\
\text { Jl. Semaun Bakri Kav 3, Serang } \\
0254-200363\end{array}$ \\
\hline \multicolumn{5}{|c|}{\begin{tabular}{|l|} 
II. Sistem Operasional Penanganan Sampah \\
A. Elemen Timbulan Sampah
\end{tabular}} \\
\hline 1. Luas wilayah (km2) & 126,15 & 164,54 & $1.110,83$ & $1.734,03$ \\
\hline 2. Jumlah penduduk (jiwa) & 1.563 .563 & 1.537 .244 & 3.324 .949 & 493.741 \\
\hline 3. Jumlah timbulan ( $\mathrm{m} 3 / \mathrm{hr})$ & $5.500(a)$ & 3446 (b) & 6851 C & $780(d)$ \\
\hline $\begin{array}{l}\text { 4. Sampah terangkut ke } \\
\text { TPA (m3/hari) }\end{array}$ & 5.279 & 846 & 1350 & 257 \\
\hline $\begin{array}{l}\text { 5. Prosentase sampah tertang- } \\
\text { gulangi }\end{array}$ & 96 & 24,6 & 19,7 & 32,9 \\
\hline 6. Komposisi sampah (\%) & & & * & * \\
\hline $\begin{array}{r}\text { Sampah Organik } \\
\text { Kertas } \\
\text { Plastik } \\
\text { Logam } \\
\text { Kaca/gelas } \\
\text { Karet } \\
\text { Kain/tekstil } \\
\text { Lain-lain } \\
\text { Total }\end{array}$ & $\begin{array}{c}65,42 \\
8,3 \\
10,39 \\
2,07 \\
1,73 \\
2,28 \\
4,14 \\
5,67 \\
100 \\
\end{array}$ & $\begin{array}{l}78,99 \\
5,81 \\
9,42 \\
0,84 \\
\\
\\
0,63 \\
4,31 \\
100 \\
\end{array}$ & & \\
\hline 7. Sumber sampah (\%) & & & * & \\
\hline $\begin{array}{r}\text { Permukiman } \\
\text { Pasar } \\
\text { Perkantoran } \\
\text { Sekolah } \\
\text { Industri } \\
\text { Lain-lain } \\
\text { Total } \\
\end{array}$ & $\begin{array}{c}52,97 \\
4 \\
27,35 \\
5,32 \\
8,96 \\
1,4 \\
100 \\
\end{array}$ & $\begin{array}{c}91,9 \\
1,86 \\
0,3 \\
1,42 \\
3,87 \\
0,65 \\
100 \\
\end{array}$ & & $\begin{array}{c}84,41 \\
2,31 \\
0,51 \\
1,96 \\
\\
10,81 \\
100 \\
\end{array}$ \\
\hline
\end{tabular}

Sumber : (a) Data Dalam Angka Sub Din Kebersihan Jak Bar, November 2006

(b) Pengelolaan Persampahan Kota Tangerang Tahun 2006, JWMC Consultant Support

c) Wawancara dengan KaBid Penanggulangan Sampah Kab Tangerang, Januari 2007

(d) Dinas PU Kab Serang, Mei 2006 (wilayah yang terlayani baru 6 kecamatan Serang kotadari 34 kecamatan yang ada)

Keterangan: * = data tidak tersedia

Tabel 4. Data Sarana Pengumpulan dan Pengangkutan Sampah di Kota Jakarta Barat, Kabupaten dan Kota Tangerang, serta Kab Serang

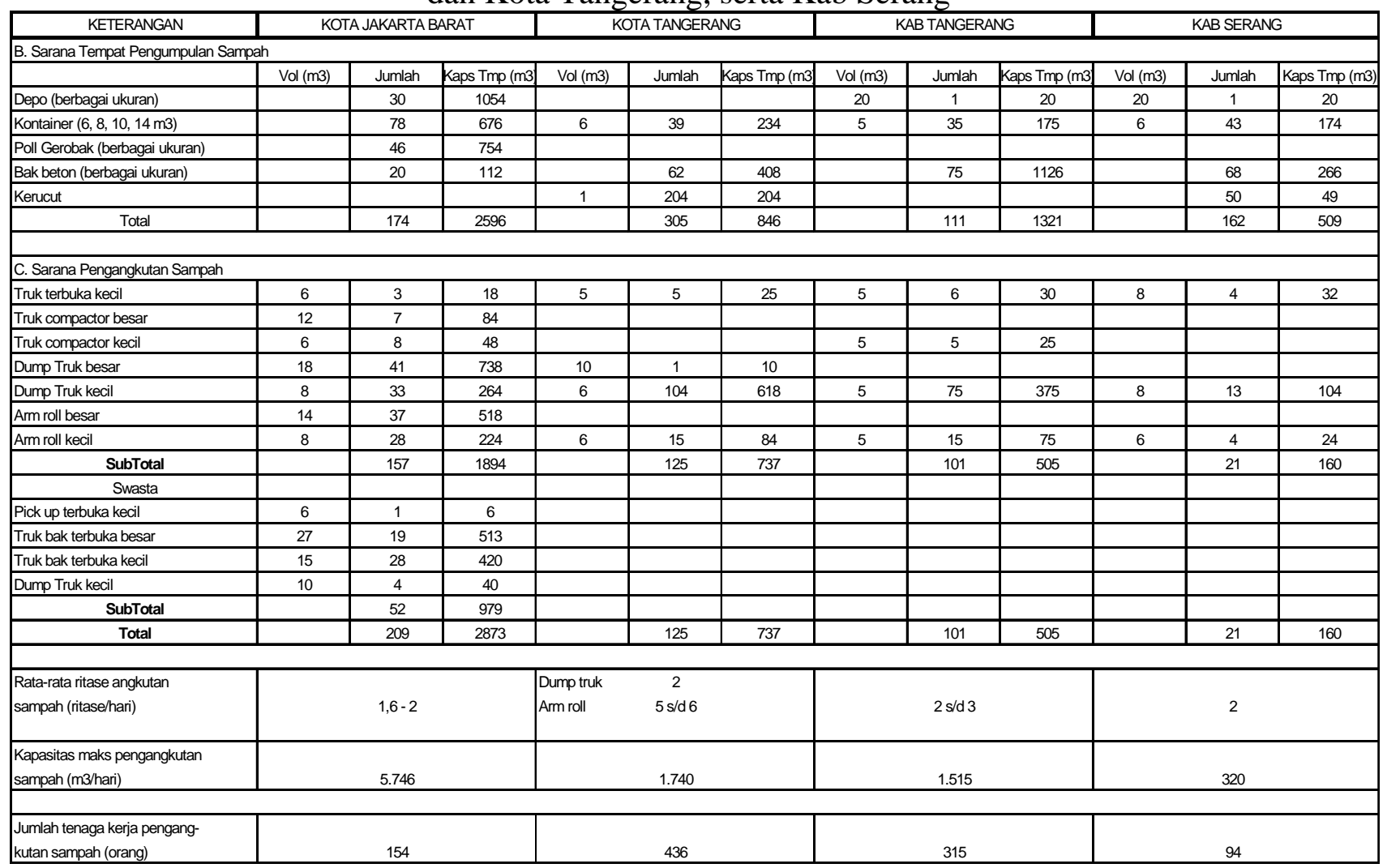

Sumber: Suku Dinas Kebersihan Kota Jakarta Barat, Kota Tangerang, Kabupaten Tangerang, dan Kabupaten Serang tahun 2006 
Sarana pengumpulan dan pengangkutan sampah yang dimiliki semua daerah penelitian jumlahnya terbatas untuk menampung timbulan sampah dalam satu hari, jadi bila kejadian darurat sampah seperti yang dialami Kota Bandung pada Februari 2005 terjadi maka dapat dipastikan sampah berserakan di sembarang tempat. Ritase pengangkutan sampah yang paling banyak adalah Kota Tangerang karena selain daerah layanannya yang kecil lokasi TPA berjarak sekitar 7 km dari pusat kota. Sedangkan Kota Jakarta Barat hanya mampu mengangkut maksimal dua rit dalam satu hari karena lokasi TPA yang jauh, yaitu di Bantar Gebang yang berjarak sekitar 63 km dan kondisi jalan yang tidak terduga kemacetan lalu lintasnya.

\section{Kondisi TPA}

Kota Jakarta Barat yang merupakan bagian dari Provinsi DKI Jakarta menempatkan sampahnya pada TPA Bantar Gebang. TPA yang sudah digunakan sejak tahun 1989 ini berat tumpukan sampahnya diperkirakan sudah mencapai 36 juta ton (Muslim, 2004). TPA yang memiliki luas 108 ha ini sudah beberapa kali dipermasalahkan keberadaannya baik oleh masyarakat di sekitar TPA yang lingkungannya sudah terdesak dengan munculnya permukiman maupun oleh kalangan anggota dewan setempat yang merasa prihatin terhadap buruknya kondisi lingkungan di TPA. Hingga saat ini Pemerintah Provinsi DKI Jakarta sebenarnya menyimpan problem yang mendesak untuk diatasi terkait dengan keberadaan satu-satunya TPA yang berada di luar daerah otonominya. Rencana membangun TPA yang lahannya sudah dibebaskan di wilayah Ciangir, Kabupaten Tangerang terganjal dengan masalah finansial yang disebabkan oleh krisis yang menimpa Indonesia tahun 1997-1998. Wilayah tersebut kemudian diubah peruntukkan lahannya oleh Pemda Kabupaten Tangerang. Tempat Pengolahan Sampah Terpadu (TPST) Bojong yang direncanakan untuk menjadi tujuan sampah DKI setelah Bantar Gebang sudah pasti tidak akan beroperasi karena penolakan yang keras dari masyarakat sekitar yang sampai menimbulkan jatuhnya korban di tahun 2004. Dalam laporan Review Rencana Induk Persampahan DKI Jakarta tahun 2005, direncanakan akan dibangun empat unit Intermediate Treatment Facility (sarana pengolahan sampah dengan teknologi menengah) untuk mengurangi jumlah timbulan sampah yang akan dibuang ke TPA.

Tiga TPA lainnya mempunyai kondisi yang tidak lebih baik daripada TPA Bantar Gebang dengan cara kerja open dumping. Ketiga TPA ini tidak dilengkapi dengan Instalasi Pengolah Air Sampah (lindi) (IPAS). Gambaran kapasitas, pengelolaan dan operasional masing-masing TPA disajikan pada Tabel 5. 
Tabel 5. Kondisi TPA di Kota Jakarta Barat, Kabupaten dan Kota Tangerang, serta Kabupaten Serang

\begin{tabular}{|c|c|c|c|c|}
\hline KEIERANGAN & $\begin{array}{c}\text { KOTA JAKARTABARAT } \\
\text { Bantargebang }\end{array}$ & $\begin{array}{l}\text { KOTATANGERANG } \\
\text { Rawa kucing }\end{array}$ & $\begin{array}{l}\text { KABTANGERANG } \\
\text { Jativaringin }\end{array}$ & $\begin{array}{l}\text { KABSERANG } \\
\text { Cilowong }\end{array}$ \\
\hline \multicolumn{5}{|c|}{ D. Tempat Pembuangan Akhir Sampah (TPA) } \\
\hline Kategori landfill & Controlled landfill & Open dumping & Open dumping & Open dumping \\
\hline Luaslahan (ha) & 108 & 8,5 & 10 & 7 \\
\hline Lahan terpakai (ha) & 83 & 7 & 6 & 4 \\
\hline Lahan tersisa (ha) & 25 & 1,5 & 4 & 3 \\
\hline Kapasitas tampung (m3) & * & * & * & * \\
\hline Volume sampah masuk (mB/hari) & 25.000 & 846 & 1.350 & 257 \\
\hline Pengelola & PT. PBB & UPIDTPA & UPIDTPA & UPTDTPA \\
\hline Tipping fee (Rp/ton) & 70.060 & * & * & * \\
\hline Pekeja operasional (orang) & & 21 & 10 & 9 \\
\hline \multicolumn{5}{|l|}{ Alat-alat berat (unit) } \\
\hline Buldozer & 16 & 4 & 1 & 1 \\
\hline Shouvel besar & 9 & 4 & & 1 \\
\hline Shouvel loader & 1 & & & \\
\hline Excavator & 10 & 2 & 2 & \\
\hline Truk & 1 & & & \\
\hline Operasional landfill & Controlled landfill & Open dumping & Open dumping & Open dumping \\
\hline Pengumpulan lindi & ada & ada & tidak ada & tidak ada \\
\hline Pengolahan lindi & ada & tidak ada & tidak ada & tidak ada \\
\hline Pengelolaan gas & tidak ada & tidak ada & tidak ada & tidak ada \\
\hline Jarak dari TPS ke TPA $(\mathrm{km})$ & 63 & 7 & 20 & 12 \\
\hline Fasilitas komposting & tidak ada & ada & tidak ada & ada \\
\hline Fasilitas 3R & tidak ada & tidak ada & tidak ada & tidak ada \\
\hline
\end{tabular}

Sumber: Suku Dinas Kebersihan Kota Jakarta barat, Kota Tangerang, Kabupaten Tangerang, dan Kabupaten Serang tahun 2006

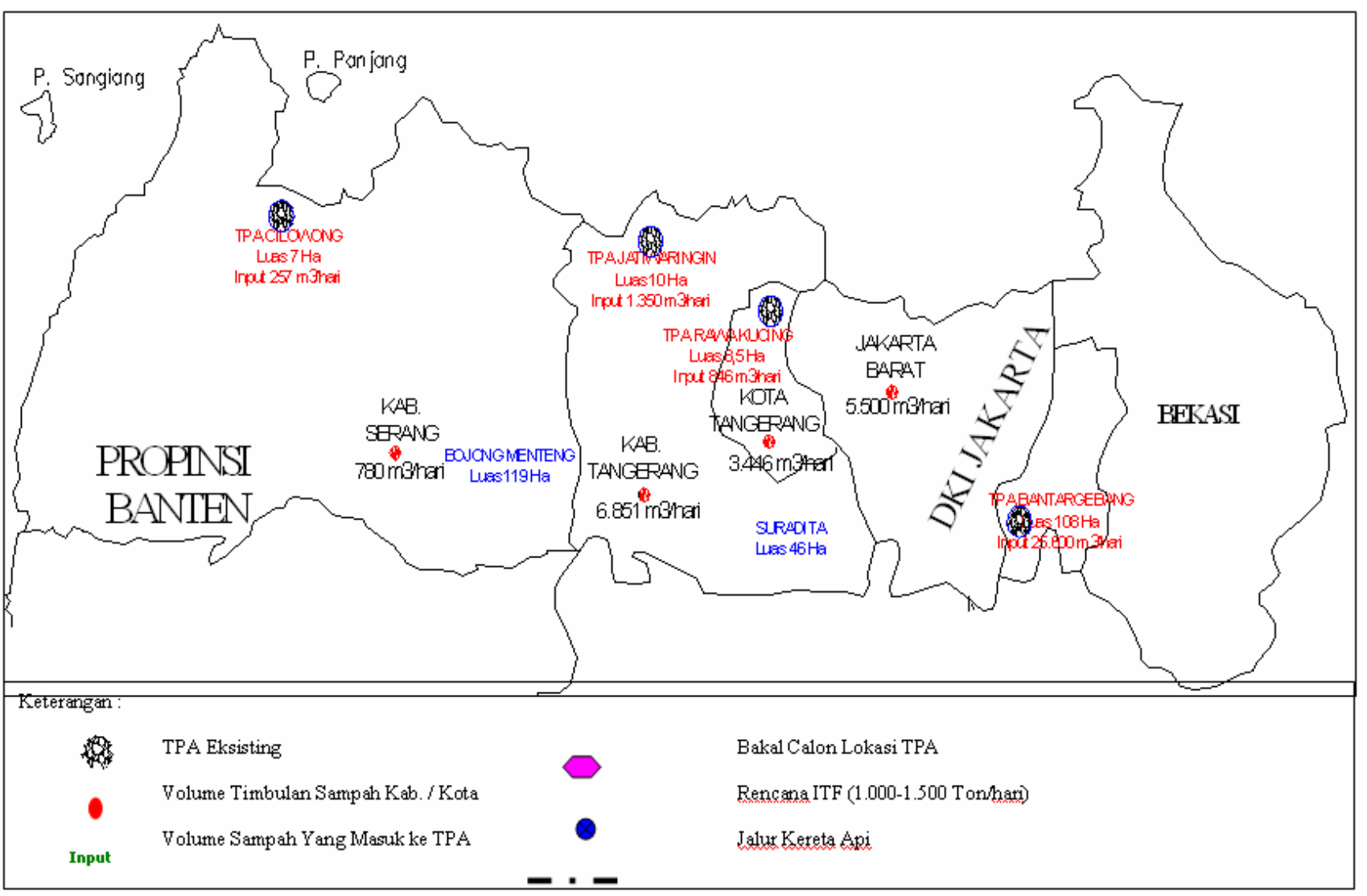

Gambar 1. Bakal calon lokasi TPA regional 
Tinjauan Bakal Calon Lokasi TPA Regional untuk Kota Jakarta Barat, Kota Tangerang, Kabupaten Tangerang, dan Kabupaten Serang

Lokasi TPA yang ideal adalah yang terletak dekat dengan sumber sampah dan adanya daya dukung lingkungan sekitarnya. Namun, dengan karakteristik daerah penelitian yang merupakan perkotaan yang padat permukiman untuk Kota Jakarta Barat dan Kota Tangerang akan cukup sulit untuk menemukan lahan kosong yang luas dan jauh dari permukiman walaupun jalur transportasi dua daerah ini untuk aksesibilitas tergolong relatif cukup baik. Kabupaten Tangerang dan Kabupaten Serang yang didominasi areal perdesaan dan daerahnya tergolong luas, yaitu masing-masing lebih dari $1100 \mathrm{~km}^{2}$ dimungkinkan untuk dipilih menjadi lokasi TPA regional. Bakal calon lokasi TPA regional yang dihubungkan dengan kondisi TPA yang ada saat ini disajikan pada Gambar 1.

\section{Analisis Teknologi Pengolahan Sampah pada TPA Regional}

Untuk mengolah sampah dengan jumlah yang begitu besar sekitar 2.600 ton per hari maka salah satu yang perlu dipertimbangkan secara matang adalah teknologi yang akan diterapkan untuk mengolah sampah dengan benar dan ramah lingkungan agar tidak kembali terulangnya kasus-kasus sebelumnya di mana TPA yang didesain untuk sanitary landfill pada akhirnya pengoperasiannya menjadi open dumping. Untuk itu, penelitian ini mengumpulkan masukan dari para pemangku kepentingan (stakeholders) bidang persampahan yang ada di daerah penelitian guna memberikan gambaran teknologi pengolahan sampah yang layak dan dapat diterima secara luas.

Teknologi pengolahan sampah yang diajukan adalah yang secara umum sudah ada di berbagai tempat lain di dunia, yaitu insinerator, pengkomposan, Sanitary Landfill, dan bioreactor landfil. Masing-masing alternatif ini dikaji menggunakan metode SWOT menurut pemikiran praktisi bidang persampahan pada daerah penelitian. Hasil yang diperoleh melalui pengumpulan pendapat para ahli tersebut disajikan pada Tabel 6.

Tabel 6. Nilai SWOT Masing-Masing Teknologi Pengolahan Sampah

\begin{tabular}{|c|c|c|c|c|c|}
\hline \multirow[t]{2}{*}{ No } & \multirow[t]{2}{*}{ Teknologi } & $\begin{array}{c}\text { Analisis Lingkungan } \\
\text { Internal }\end{array}$ & $\begin{array}{c}\text { Analisis Lingkungan } \\
\text { Eksternal }\end{array}$ & \multirow{2}{*}{$\begin{array}{c}\text { Nilai } \\
\text { Tengah }\end{array}$} & \multirow{2}{*}{$\begin{array}{c}\text { Nilai } \\
\text { Maksimum }\end{array}$} \\
\hline & & Skor Gabungan S-W & Skor Gabungan O-T & & \\
\hline 1 & Insinerator & 2.49 & 2.41 & 2.5 & 4 \\
\hline 2 & Pengkomposan & 2.54 & 2.59 & 2.5 & 4 \\
\hline 3 & $\begin{array}{l}\text { Bioreactor } \\
\text { Landfill }\end{array}$ & 2.42 & 2.71 & 2.5 & 4 \\
\hline 4 & Sanitary Landfill & 2.46 & 2.6 & 2.5 & 4 \\
\hline
\end{tabular}

Sumber: Hasil pengolahan data kuisioner 
Berdasarkan Tabel 6 dari empat teknologi yang ada yang melampaui nilai tengah baik dari skor faktor lingkungan internal maupun eksternalnya adalah pengkomposan.

Sesuai dengan alternatif TPA regional dengan bakal calon lokasi di wilayah Bojong Menteng, maka sampah yang berasal dari Kabupaten Serang akan diangkut langsung ke lokasi TPA regional sedangkan dari Kota Jakarta Barat, Kota Tangerang, dan Kabupaten Tangerang melalui SPA di wilayah Suradita dengan menggunakan jalur kereta api. Oleh karena itu untuk menghitung pembiayaan yang terkait dengan tipping fee maka seluruh fasilitas yang mendukung TPA regional ini yaitu fasilitas pengkomposan kapasitas 500 ton/hari dan sanitary landfill kapasitas 2100 ton/hari serta SPA kapasitas 1500 ton/hari harus dikalkulasikan biaya investasi dan biaya operasionalnya. Ringkasan estimasi biaya investasi disajikan pada Tabel 7.

Tabel 7. Estimasi Biaya Investasi TPA Regional

\begin{tabular}{|l|l|c|}
\hline No. & \multicolumn{1}{|c|}{ Uraian } & Total Biaya (Rp) dlm ribuan \\
\hline 1. & Pembebasan lahan TPA 119 ha & 11.900 .000 \\
\hline 2. & $\begin{array}{l}\text { Pembangunan pengkomposan plant 500 ton/hari + } \\
\text { Pembangunan sanitary landfill 2100 ton/hari }\end{array}$ & 98.700 .000 \\
\hline 3. & Pembebasan lahan SPA 10 ha & 4.000 .000 \\
\hline 4. & Pembangunan SPA 1500 ton/hari & 86.600 .000 \\
\hline 5. & Pra konstruksi (perijinan, perencanaan, pengawasan, dll) & 6.000 .000 \\
\hline & Total & 207.200 .000 \\
\hline
\end{tabular}

Sumber:DED TPA RSL in East Serang (2004) dan Paparan Konsultan JWMC 2006

Berdasarkan asumsi bahwa proyek dapat beroperasi pada awal tahun 2010 maka nilai tipping fee diperkirakan Rp. 116.000,00 yang terdiri atas tipping fee di SPA sebesar Rp. 55.000,00 dan tipping fee di TPA sebesar Rp. 61.000,00 (diolah dari Paparan konsultan JWMC, 2006 dan studi Pra FS TPST Regional Pasar Kemis, 2006). Asumsi biaya yang dianggarkan pada Tabel 7 masih mempertimbangkan biaya-biaya fisik bangunan sementara pada kenyataannya permasalahan pembangunan TPA memerlukan penyelesaian pendekatan sosial pada masyarakat. Contohnya saja Pemda DKI untuk TPA Bantargebang menyediakan anggaran 20\% dari tipping fee sebagai alokasi biaya sosial (uang kebauan) bagi masyarakat sekitar. Biaya sosial ini dapat dialokasikan setelah dilakukannya studi daya dukung sosial masyarakat di sekitar lokasi TPA nantinya. Sehingga bisa diketahui fasilitas atau sarana apa yang masih kurang untuk mendukung perbaikan kondisi sosial budaya masyarakat. Jadi nantinya biaya sosial ini diberikan dalam bentuk bantuan terhadap pembangunan fasilitas sosial seperti tempat peribadatan atau program pemberdayaan masyarakat dan bukannya pembagian uang semata.

Dengan melakukan analisis manfaat dan biaya pengolahan sampah pada TPA regional dapat diketahui apakah nilai tipping fee yang dihitung berdasarkan total biaya + total investasi masih bisa 
ditutupi dengan manfaat yang didapat. Berdasarkan perhitungan (pada lampiran) didapatkan nilai $\mathrm{B} / \mathrm{C}$ (perbandingan manfaat dengan biaya) $=1,09$ untuk analisis manfaat biaya tanpa penjualan kompos. Sedangkan dengan penjualan kompos menjadi nilai B/C 1,27. Hal ini berarti bahwa secara kelayakan dari aspek ekonomi maupun pertimbangan aspek manfaat lingkungan TPA regional ini bisa berjalan dengan nilai tipping fee sebesar Rp. 116.000,-. Jika ditinjau lebih jauh lagi, TPA regional dengan fasilitas pengkomposan akan memberi manfaat sosial, yaitu memberikan pendapatan masyarakat sekitar yang menjadi pekerja sehingga pendapatan yang diterima dapat dikonversi nilainya sebagai penerimaan pengelola TPA yang tentunya dapat memperbesar nilai B/C dari yang sebelumnya.

\section{Analisis Kelembagaan TPA Regional}

Masing-masing daerah memiliki bentuk instansi yang berbeda-beda dalam pengelolaan sampah. DKI Jakarta melalui dinas kebersihan untuk tingkat provinsi dan di bawahnya langsung setingkat suku dinas untuk masing-masing kotamadya.

Keberadaan masing-masing instansi pengelola persampahan di daerah yang dikuatkan melalui peraturan yang dikeluarkan masing-masing daerah mempunyai tugas pokok pelayanan publik dalam pengelolaan sampah. Namun pelaksanaannya yang tanpa pengawasan secara sistemik membuat sangat sulit untuk diukur atau dinilai kefektifan dan efesiensi instansi pengelola sampah.

Untuk melakukan kerjasama antar daerah dalam pengelolaan sampah yang diimplementasikan dalam konsep TPA regional maka, fungsi yang diemban lembaga TPA regional adalah sebagai berikut:

1. Menampung semua sampah dari area pelayanan yang dibawa oleh Instansi pengelola kebersihan sampah kota atau lainnya. Sampah yang diangkut kendaraan milik Pemda akan diterima di SPA dan TPA yang akan dibangun dan/atau dioperasikan oleh lembaga TPA regional.

2. Mengangkut sampah yang diterima di SPA menuju TPA yang dioperasikan oleh lembaga TPA regional dengan menggunakan angkutan yang sesuai.

Menerima dan mengolah sampah yang terkumpul di TPA (dibangun dan/atau dioperasikan oleh lembaga TPA regional), dengan memanfaatkan teknologi pengkomposan dan sanitary landfill sesuai dengan stándar yang berlaku.

Daerah cakupan pada penelitan ini terdiri atas dua provinsi yaitu, Banten dan DKI sehingga pembentukan kerjasama antar daerahnya juga relatif lebih rumit. Bentuk badan kerjasama antar daerah yang mungkin untuk diterapkan pada daerah penelitan disajikan pada Tabel 8. 
Tabel 8. Matriks Institusi Calon Pengelola TPA Regional

\begin{tabular}{|l|l|l|l|l|}
\hline No. & Bentuk Institusi & \multicolumn{1}{|c|}{ Payung Hukum } & \multicolumn{1}{|c|}{ Mekanisme Keuangan } & \multicolumn{1}{c|}{ Mekanisme SDM } \\
\hline 1. & BUMD & $\begin{array}{l}\text { Diperlukan aspek legal baru } \\
\text { Dapat mengakomodir kepentingan } \\
\text { masing-masing daerah } \\
\text { Aturan pembentukannya tercantum } \\
\text { dalam UU No 5 Tahun 1962 }\end{array}$ & $\begin{array}{l}\text { Lebih fleksibel dan otonom } \\
\text { Modal berasal dari masing-masing } \\
\text { pemda melalui mekanisme perda } \\
\text { terkait sistem kepegawaian PNS }\end{array}$ & $\begin{array}{l}\text { Jumlah personil disesuaikan kegia- } \\
\text { tan perusahaan }\end{array}$ \\
\hline 2. & Badan Layanan Umum & $\begin{array}{l}\text { Aturan pembentukannya dapat me- } \\
\text { nggunakan PP No 23 Tahun } \\
\text { 2005 tentang Pengelolaan Keuang- } \\
\text { an Badan Layanan Umum }\end{array}$ & $\begin{array}{l}\text { Lebih otonom karena dibuat berda- } \\
\text { sarkan rencana kerja tahunan dan } \\
\text { harus dapat diakses publik }\end{array}$ & Lebih otonom \\
\hline 3. & Korporasi swasta (PT) & $\begin{array}{l}\text { Harus ada kontrak dengan salah sa } \\
\text { tu pemda } \\
\text { PT yang berminat harus melalui } \\
\text { proses tender }\end{array}$ & $\begin{array}{l}\text { Lebih otonom dan fleksibel } \\
\text { Biaya investasi yang dikeluarkan } \\
\text { harus kembali sesuai jangka wak } \\
\text { tu kontrak }\end{array}$ & $\begin{array}{l}\text { Lebih otonom dan fleksibel } \\
\text { tan perusahaan }\end{array}$ \\
\hline
\end{tabular}

Sumber: Paparan Konsultan JWMC (2006)

Pembentukan kelembagaan pengelola TPA regional sebaiknya dibicarakan oleh masing-masing Pemda dengan melihat kondisi aspek pendanaan yang paling memungkinkan. Setelah komitmen pendanaan dari masing-masing pihak yang terkait sudah jelas, maka tentunya kelembagaan yang paling tepat dapat dengan jelas dipertimbangkan keuntungan dan kerugiannya dari masing-masing bentuk institusinya.

Bentuk kelembagaan pengelola TPA regional untuk daerah penelitian ini sangat bergantung pada kerjasama antar kepala daerah yang terkait. Proses awal penandatanganan SKB hanyalah permulaan untuk perumusan lebih lanjut karena akan dibutuhkan Perda yang terkait dengan kerjasama pengelolaan sampah dan juga melakukan revisi terhadap Perda yang mengatur institusi pengelola persampahan daerah masing-masing.

Kelembagaan TPA regional pada daerah penelitian ini mengacu pada struktur kelembagaan Sarbagita hanya tingkatannya lebih luas lagi karena menyangkut daerah-daerah dalam dua provinsi yang berbeda. Analisis kelembagaan pengelolaan sampah regional disajikan pada Gambar 2.

Berdasarkan Gambar 2, pembagian fungsi regulator, operator, dan pengawas merupakan bagian yang harus ada dalam sistem pelayanan publik, dalam hal ini termasuk pengelolaan sampah. Keberadaan badan yang memiliki tugas pokok dan fungsi-fungsi tersebut harus diatur dalam payung hukum peraturan perundang-undangan. Begitu juga mengenai mekanisme siapa saja yang menjadi anggota tim dalam badan-badan tersebut harus jelas disebutkan dan mewakili semua pihak yang menjadi pemangku kepentingan dalam pengelolaan sampah. 


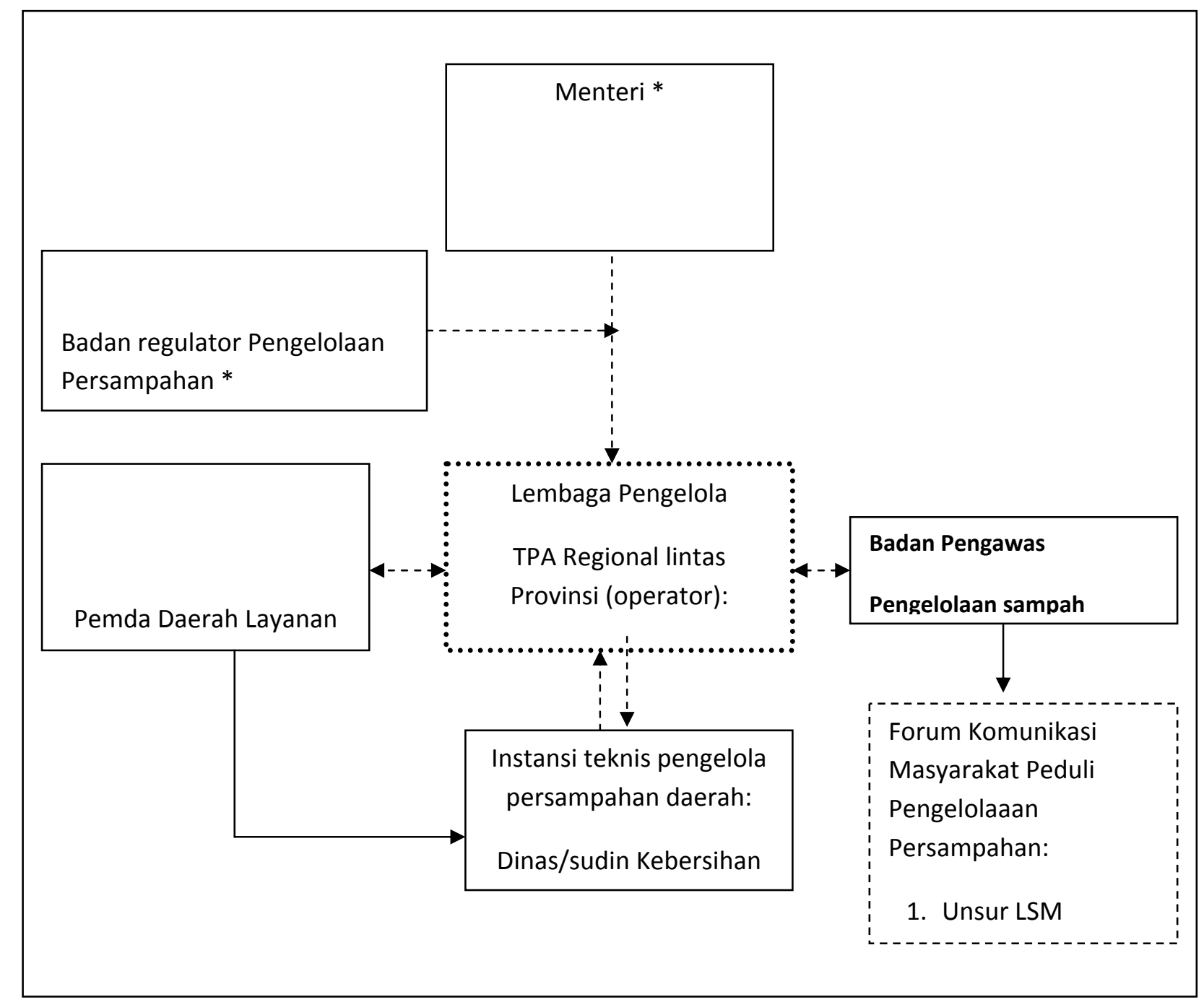

Keterangan: Garis: Tanggung jawab struktural, Garis putus-putus: Fungsi koordinasi

* Merujuk RUU Pengelolaan Sampah

Gambar 2. Kelembagaan Pengelolaan Sampah Dengan Adanya TPA Regional

(Sumber: Modifikasi dari PT. Waseco Tirta, 2006 dan Kementerian Lingkungan Hidup, 2006)

Lembaga pengelola TPA regional sendiri bentuk BLU nampaknya lebih mengakomodasi berbagai faktor yang mempengaruhi operasional pengelolaan sampah baik itu dari segi pendanaan dan institusi sehingga akan mendukung berjalannya TPA regional dengan baik. Dalam BLU sendiri terdiri atas pengelola BLU, dewan pengawas, dan pegawai BLU. BLU lebih dipilih karena karakteristinya yang berkedudukan sebagai lembaga pemerintah (bukan kekayaan negara yang dipisahkan), menghasilkan barang/jasa yang seluruhnya/sebagian dijual kepada publik, tidak bertujuan mencari keuntungan (laba), dikelola secara otonom dengan prinsip efisiensi dan produktivitas ala korporasi, rencana kerja/anggaran dan pertanggung jawaban dikonsolidasikan pada instansi induk, pendapatan dan sumbangan dapat digunakan langsung, pegawai dapat terdiri dari PNS dan Non-PNS, bukan sebagai subjek pajak. Ini tentunya lebih sesuai jika dibandingkan dengan BUMD yang tujuan mencari keuntungan dan sebagai sumber pendapatan pemerintah daerah serta korporasi swasta yang jelas-jelas keberlangsungan hidupnya atas profit dari barang/jasa yang dihasilkan. 


\section{Kesimpulan dan Saran}

\section{Kesimpulan}

Berdasarkan penelitian yang telah dilakukan dan hasil yang diperoleh dapat diambil kesimpulan sebagai berikut:

a. Hasil pemilihan teknologi pengolahan sampah dengan analisis SWOT untuk TPA regional daerah Kota Jakarta Barat, Kabupaten dan Kota Tangerang, serta Kabupaten Serang adalah pengkomposan dan sanitary landfill. Pengkomposan memiliki skor tertinggi dan sanitary landfill memiliki skor tertinggi berikutnya.

b. Pembiayaan TPA regional daerah Kota Jakarta Barat, Kabupaten dan Kota Tangerang, serta Kabupaten Serang membutuhkan dana sekitar Rp 207 milyar. Dana tersebut dapat dihimpun melalui APBN, APBD masing-masing Pemda serta tarif retribusi kebersihan yang telah disesuaikan besarnya.

c. Lembaga pengelola TPA regional berbentuk BLU dengan dukungan lembaga lainnya yang disesuaikan dengan RUU Pengelolaan Sampah dan RPP Kerjasama Antar Daerah.

\section{Saran}

Saran untuk mendukung terlaksananya TPA regional daerah layanan Kota Jakarta Barat, Kabupaten dan Kota Tangerang, serta Kabupaten Serang antara lain:

a. Melakukan studi daya dukung sosial pada bakal calon lokasi TPA regional untuk mengetahui potensi penerimaan masyarakat terhadap rencana TPA regional.

b. Memulai proses kerjasama antar daerah di bidang persampahan sesuai dengan arahan SE Mendagri Nomor 120/1730/SJ tanggal 13 Juli 2005.

c. Masing-masing daerah melakukan studi mengenai kesediaan masyarakat membayar retribusi kebersihan dan cara yang efektif untuk penarikan retibusi.

d. Merencanakan penyesuaian tugas pokok dan fungsi (tupoksi) instansi teknis pengelola persampahan daerah dengan mekanisme kelembagaan baru dengan adanya TPA regional.

\section{Daftar Pustaka}

Amurwaraharja, I. (2003). Analisis Teknologi Pengolahan Sampah dengan Proses Hirarki Analitik dan Metode Valuasi Kontingensi (Studi Kasus di Jakarta Timur), Tesis, Bogor.

Bebassari, S. (2004). Sistem Pengelolaan Sampah Kota Secara Terpadu, Modul Pelatihan Pengelolaan Sampah Kota Secara Terpadu Menuju Zero Waste, Jakarta. 
BPPT. (2004). Modul Pelatihan Pengelolaan Sampah Kota Secara Terpadu Menuju Zero Waste, Jakarta.

Budirahardjo, E. (2004). Analisis SWOT (Studi Kasus Penanganan Sampah DKI Jakarta dengan Cara Bio-Teknologi), Jakarta.

Cointreau, S. (2005). Solid Waste Financing in Developing Countries. Presentation Slide, World Bank, Washington DC.

Departemen PU. (1999). Kajian Pengelolaan Kertas, Laporan Penelitian, Jakarta.

Dinas Kebersihan Provinsi DKI Jakarta. (2007). Informasi Pengelolaan Kebersihan Tahun 2006, Jakarta.

Dinas Permukiman Provinsi Jawa Timur. (2002). Laporan Akhir Penyusunan Studi Pengelolaan TPA dan Pengelolaan Sampah Terpadu. Surabaya.

Hornweg, D. (2000). Composting and Its Applicability in Developing Countries, Working Paper Series, World Bank. Washington DC.

JICA, PT Arkonin. (2004). Solid Waste Data in Indonesia, Project Final Report, Jakarta.

Kusumaastuti, D. (2004). Kajian Manfaat Dan Biaya Pengelolaan Sampah Terpadu (studi kasus: TPS Rawa Kerbau, Jakarta Pusat), Tesis, Jakarta.

PT Alpindo Arga Cipta. (2006). Laporan Studi Kelembagaan TPA Regional, Jakarta. 